\title{
Mission Impossible? : Pope Benedict XVI and Interreligious Dialogue
}

\author{
Anton, Emil
}

2017-12

Anton , E 2017 , ' Mission Impossible? Pope Benedict XVI and Interreligious Dialogue ' ,

Theological Studies, vol. 78 , no. 4 , pp. 879-904 . https://doi.org/10.1177/0040563917731744

http://hdl.handle.net/10138/237047

https://doi.org/10.1177/0040563917731744

acceptedVersion

Downloaded from Helda, University of Helsinki institutional repository.

This is an electronic reprint of the original article.

This reprint may differ from the original in pagination and typographic detail.

Please cite the original version. 


\title{
Mission Impossible? Pope Benedict XVI and Interreligious
}

\section{Dialogue}

\section{Emil Anton}

University of Helsinki, Vantaa (Finland)

\begin{abstract}
There exist very different accounts about the attitude of Joseph Ratzinger/Pope Benedict XVI to interreligious dialogue. Does interreligious dialogue aim at truth and intertwine with mission, or is it an impossibility that needs to be replaced with an intercultural dialogue about peaceful coexistence and common values? This article traces the complex history and relationship of these views from the 1990s, through the much-misunderstood letter to Marcello Pera in 2008, until Benedict's retirement. Despite impressions to the contrary, Pope Benedict XVI's commitment to interreligious dialogue remains firm.
\end{abstract}

\section{Keywords}

Benedict XVI, evangelization, intercultural dialogue, interreligious dialogue, mission, proclamation, Marcello Pera, Joseph Ratzinger, truth 
The study of Pope Benedict XVI's vision of interreligious dialogue presents a peculiar problem. ${ }^{1}$ Both in the writings and speeches of Joseph Ratzinger/Pope Benedict XVI and in the literature about him, there appear two lines of thought that seem unrelated and difficult to reconcile with each other. According to the first one, Ratzinger saw interreligious dialogue as aiming at truth and thus being closely related to evangelization. According to the second one, Benedict treated interreligious dialogue, or at least theological dialogue, as an impossibility, calling instead for an intercultural dialogue about common values and human rights.

How is one to make sense of these two very different lines of thought? Strangely, there has been virtually no attempt at relating them to each other, with commentators regularly ignoring either one of the two paradigms. Certainly, general tensions between various currents in Ratzinger/Benedict's writings and speeches about interreligious dialogue have been detected by theologians, but in the end the analyses have remained superficial. For example, Thomas P. Rausch's brief comparison of different sources leads him to see Ratzinger as "somewhat ambivalent in regard to dialogue with non-Christian traditions." ${ }^{2}$ Gregory Baum has suggested a shift from a negative view to a positive one ${ }^{3}$ while Peter C. Phan has detected a development in

${ }^{1}$ I would like to thank Felix Körner, SJ, Daniel Madigan, SJ, Archbishop Michael L. Fitzgerald, Giuseppe Tanzella-Nitti, Oskari Juurikkala, Valentino Cottini, John L. Allen Jr., and the community of the Lay Centre at Foyer Unitas in Rome, especially Donna Orsuto and A. J. Boyd, for valuable conversations during the formative period of this article.

${ }^{2}$ Thomas P. Rausch, Pope Benedict XVI: An Introduction to His Theological Vision (New York: Paulist, 2009), 63.

${ }^{3}$ Gregory Baum, "Interreligious Dialogue: A Roman Catholic Perspective," Global Media Journal - Canadian Edition 4 (2011): 5-20 at 10-12, http://www.gmj.uottawa.ca/1101/v4i1_baum.pdf. 
the opposite direction. ${ }^{4}$ However, no simplistic conversion story is able to do justice to the entirety of the evidence, which rather suggests a puzzling zigzag. ${ }^{5}$ Other examples of inadequate interpretations will be encountered during the course of this article, which now proposes to examine the issue in detail.

The article combines a thematic and a chronological approach by focusing on what will be called the "truth/mission model" and the "culture/values model" from the late 1990s until the end of Benedict XVI's pontificate. It will be seen that the dilemma concerns both the personal writings of Joseph Ratzinger and the official speeches of Pope Benedict, the latter reflecting the same problems as the former, thus raising them to the platform of magisterial teaching.

\footnotetext{
${ }^{4}$ Peter C. Phan, foreword to Dialogue Derailed: Joseph Ratzinger's War Against Pluralist
} Theology, by Ambrose Ih-Ren Mong (Eugene: Pickwick, 2015), ix-x at ix. Mong himself expresses the tension, left unsolved, as follows: "Somewhat paradoxically, [Ratzinger] strongly believes in dialogue with other religions, while stressing the church's evangelizing mission." Mong, Dialogue Derailed, xvi.

${ }^{5}$ For example, Baum argues that Benedict was suspicious of interreligious dialogue and refused to recognize "anything of God" in other religions up to 2006-2007. He is then supposed to have undergone a "dramatic evolution" thanks to A Common Word, turning him into a promoter of interreligious dialogue in 2008-2009. This view does not take into account Ratzinger's positive attitude toward interreligious dialogue since 1997, nor his distinction between authentic and relativistic dialogue. Furthermore, it confuses Ratzinger's personal opinions with the official text of Dominus Iesus, and does not consider the import of the (apparently negative) letter to Marcello Pera in late 2008. 


\section{Ratzinger at the Turn of the Millennium}

As prefect of the Congregation for the Doctrine of the Faith (CDF), Joseph Cardinal Ratzinger turned his attention to the issue of world religions in the 1990s. In 1997, he authored an article called "The Dialogue of the Religions and the Relationship between Judaism and Christianity," first published in Communio, then reprinted in the small volume Many Religions - One Covenant: Israel, the Church and the World. ${ }^{6}$ In 2000, he presented to the world Dominus Iesus, the much-discussed official CDF document, and wrote a new preface to his classic Introduction to Christianity, in which he called attention to the new "context of interreligious discussions."7 A few years later, Ratzinger released Truth and Tolerance: Christian Belief and World Religions, which is a collection of writings dating mostly from the years $1992-2003 .{ }^{8}$ These texts are the main sources for studying Ratzinger's prepapal views on interreligious dialogue, with the important specification that it is in Ratzinger's presentation of Dominus Iesus, not Dominus Iesus itself, where his personal opinions on the matter are expressed. ${ }^{9}$

\footnotetext{
${ }^{6}$ Joseph Ratzinger, Many Religions - One Covenant: Israel, the Church and the World, trans. Graham Harrison (San Francisco: Ignatius, 1999).

${ }^{7}$ Joseph Ratzinger, preface to the new edition of Introduction to Christianity, by Joseph Ratzinger (San Francisco: Ignatius, 2004), 11-29 at 29.

${ }^{8}$ Joseph Ratzinger, Truth and Tolerance: Christian Belief and World Religions, trans. Henry Taylor (San Francisco: Ignatius, 2004).

${ }^{9}$ Congregation for the Doctrine of the Faith, Dominus Iesus (August 6, 2000), http://www.vatican.va/roman_curia/congregations/cfaith/documents/rc_con_cfaith_doc_2000080

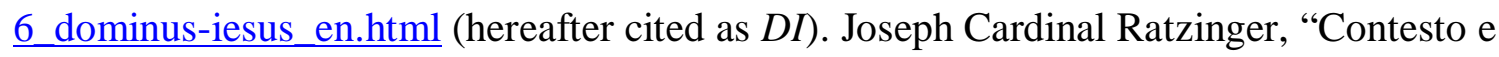




\section{Dialogue Aims at Truth}

According to Joseph Ratzinger, what is the ultimate goal of interreligious dialogue? We can take as our starting point the cardinal's statement that interreligious dialogue does not aim at the unification of all the various religions. ${ }^{10}$ Thus, it differs from classical ecumenism, which aims at a visible and full unity of Christians. If this is so, does interreligious dialogue then aim at making “one another better Christians, Jews, Moslems, Hindus or Buddhists”? Let us hear Ratzinger's response:

My answer is No. For this would be nothing other than total lack of conviction ... we would be finally renouncing truth. Rather, the answer must be that mission and dialogue

significato della Dichiarazione 'Dominus Iesus', https://press.vatican.va/content/salastampa/it/bollettino/pubblico/2000/09/05/0518/01756.html\#INTERVENTO\%20 DEL\%20CARD.\%20JOSEPH\%20RATZINGER. There are at least two English translations, both with serious deficiencies. See Joseph Ratzinger, Pilgrim Fellowship of Faith: The Church as Communion, trans. Henry Taylor (San Francisco: Ignatius, 2005), 209-16, and http://www.oasiscenter.eu/articles/magisterium/2009/04/20/presentation-of-the-declaration-dominus-iesus-by-h-emcardinal-joseph-ratzinger-now-his-holiness-pope-benedict-xvi-vatican-c. It must be stressed that Ratzinger was not the author of Dominus Iesus, as he has recently confirmed in Pope Benedict XVI and Peter Seewald, Last Testament: In His Own Words, trans. Jacob Phillips (New York, Bloomsbury, 2016), 172.

${ }^{10}$ Ratzinger, Many Religions, 109. 
should no longer be opposites but should mutually interpenetrate. Dialogue is not aimless conversation; it aims at conviction, at finding the truth; otherwise it is worthless. ${ }^{11}$ Interreligious dialogue is thus seen as a worthy and useful endeavor, as long as it aims at finding the truth. Dialogue is not opposed to mission but intertwined with it. It does not aim at a unification of all religions, but it does seem to aim at the conversion of individual nonChristians. ${ }^{12}$

${ }^{11}$ Ratzinger, Many Religions, 111-12.

${ }^{12}$ See also Ratzinger, Truth and Tolerance, 120, quoted below. Ratzinger here ties dialogue and mission more closely together than the 1984 document of the Pontifical Council for Interreligious Dialogue (PCID), Dialogue and Mission, as well as the 1991 PCID document Dialogue and Proclamation. There is also an important difference in terminology. DM and DP use the term "evangelizing mission" in a broad sense, covering "presence and witness; commitment to social development and human liberation; liturgical life, prayer and contemplation; interreligious dialogue; and finally, proclamation and catechesis," whereas Ratzinger/Benedict uses the terms "mission" and "evangelization" in a narrower sense, equivalent to what DP calls "proclamation", defined as an "invitation to a commitment of faith in Jesus Christ and to entry through baptism into the community of believers which is the Church." The Ratzingerian usage will be followed in this article. On the terminology, see Pontifical Council for Interreligious Dialogue, Dialogue and Proclamation (May 19, 1991), 2, 8, 10, http://www.vatican.va/roman curia/pontifical councils/interelg/documents/rc pc interelg doc 19051991 dialogue-and-proclamatio en.html (hereafter cited as DP). On dialogue and conversion, see $D P$ 41. See also Pontifical Council for Interreligious Dialogue, Dialogue and Mission (June 10, 1984), http://www.pcinterreligious.org/dialogue-and-mission_75.html. 


\section{God Is Greater}

But does this mean that for Ratzinger, interreligious dialogue is simply about proclamation, about converting others, as some scholars have suggested ${ }^{13}$ Is dialogue afailure if the non-

${ }^{13}$ James Corkery, Joseph Ratzinger's Theological Ideas: Wise Cautions \& Legitimate Hopes (New York: Paulist, 2009), 96-105; Matthew S. Lopresti, “Inter-religious Dialogue and Religious Pluralism: A Philosophical Critique of Pope Benedict XVI and the Fall of Religious Absolutism," in Philosophical Basis of Inter-Religious Dialogue: The Process Perspective, ed. Miroslaw Patalon (Cambridge: Cambridge Scholars, 2009, 66-94, http://www.academia.edu/335676/INTER-

RELIGIOUS_DIALOGUE_AND_RELIGIOUS_PLURALISM_A_Philosophical_Critique_of_Pope_Benedict_XVI and the Fall of Religious_Absolutism (page numbers refer to web version). According to Corkery, dialogue for Ratzinger is "much less about hearing from, appreciating and being enriched by the other than it is simply about proclamation" (100). Corkery mistakenly assumes Ratzinger authored DI and takes the collaborative CDF document as his starting point. This leads to surprise on Corkery's part $(103,105)$ at Ratzinger/Benedict's own texts, which are more positive and contradict the analysis cited above. This assumption is also apparent in Rausch and Mong, the latter fully aware that DI was "not written by Ratzinger." Mong, Dialogue Derailed, 30. According to Lopresti, Ratzinger sees only two uses for interreligious dialogue: "first, to work towards mutual understanding, and second, to use that gained understanding to effectively exploit the vulnerability of the other's honest and open engagement so as to undermine her faith in her own tradition" (13). Lopresti confuses Ratzinger's ideas with those of Marcello Pera, and 
Christian does not convert to Christianity? The answer to both questions is a resounding no. In fact, before even mentioning the missionary aspect, which comes at the very end of the article, Ratzinger shows a remarkable openness in his attitude toward interreligious dialogue. According to Ratzinger, God's Word always "far surpasses all human words," and in God's kenosis religions can meet "without claims of sovereignty." Moreover, we "must always look for what is positive in the other's beliefs," and we ought to be "ready to accept criticism of ourselves and our own religion."14

What we need ... is respect for the beliefs of others and the readiness to look for the truth in what strikes us as strange or foreign; for such truth can correct us and lead us farther along the path. What we need is the willingness to look behind the alien appearances and look for the deeper truth hidden there.

Furthermore, I need to be willing to allow my narrow understanding of truth to be broken down. I shall learn my own truth better if I understand the other person and allow myself to be moved along the road to the God who is ever greater, certain that I never hold the whole truth about God in my own hands but am always a learner, on pilgrimage toward it, on a path that has no end. ${ }^{15}$

Ratzinger insists interreligious dialogue cannot proceed by abandoning the truth but by a deeper entering into it. In this process, the Christian is never supposed to be only the giver but also the

he relies on only one Ratzinger quote to make the argument. This approach does not take into account a host of other statements to the contrary, such as the 1997 article under discussion.

${ }^{14}$ Ratzinger, Many Religions, 108-11.

${ }^{15}$ Ratzinger, Many Religions, 109-10. 
receiver. ${ }^{16}$ He can profit and learn from the other's otherness, purify his own faith and be led forward on the path to God who is always greater-Allahu akbar, as the Arabic has it. Ratzinger repeats the point in the new preface to Introduction to Christianity, specifying that the "mystical dimension of the concept of God, which the Asian religions bring with them as a challenge to us, must clearly be decisive for our thinking, too, and for our faith." 17

God has become quite concrete in Christ, but in this way his mystery has also become still greater. God is always infinitely greater than all our concepts and all our images and names. The fact that we now acknowledge him to be triune does not mean that we have meanwhile learned everything about him. ${ }^{18}$

In his analysis of Ratzinger's approach to interreligious dialogue, Francis X. Clooney is right to note that the quest for truth cannot simply mean, "We have the truth; they are searching for it." Rather, it "obliges everyone involved, and what is learned will have consequences even for those of us who, by grace, know Jesus." ${ }^{19}$ Ratzinger is thus as firmly committed to authentic interreligious dialogue as he is opposed to relativism.

\footnotetext{
${ }^{16}$ Ratzinger, Many Religions, 109, 112.

${ }^{17}$ Ratzinger, preface to Introduction to Christianity, 25.
}

18 Ibid.

${ }^{19}$ Francis X. Clooney, "Dialogue Not Monologue: Benedict XVI \& Religious Pluralism,” Commonweal, October 17, 2005, https://www.commonwealmagazine.org/dialogue-notmonologue. Rocco Viviano similarly concludes that for Pope Benedict, interreligious dialogue is a "joint quest for the truth" (316). Although Viviano's classification of other goals such as peace and religious freedom as "intermediary goals" (213-214) may be helpful, Viviano does not address the tension examined here, nor treat of Marcello Pera. Rocco Viviano, "The Theological- 


\section{Authentic and Relativistic Dialogue}

Against the popular idea that Ratzinger, as prefect of the CDF, adopted a negative attitude toward interreligious dialogue, it is crucial to note that Ratzinger makes a distinction between two different ideas of dialogue: the traditional and authentic one, which he endorses, and the new and relativistic one, which he rejects. In Truth and Tolerance, Ratzinger writes:

Thus to a great extent the concept of dialogue, which certainly held an important place in the Platonic and in the Christian tradition, has acquired a different meaning. It has become the very epitome of the relativist credo, the concept opposed to that of "conversion" and mission: dialogue in the relativist sense means setting one's own position or belief on the same level with what the other person believes, ascribing to it, on principle, no more of the truth than to the position of the other person. Only if my fundamental presupposition is that the other person may be just as much in the right as I am, or even more so, can any dialogue take place at all. Dialogue, it is said, has to be an exchange between positions that are fundamentally of equal status and thus mutually relative, with the aim of achieving a maximum of cooperation and integration between various religious bodies and entities. ${ }^{20}$

Ecclesiological Thought of Benedict XVI (2005-2013) on the Christian Engagement with the Religions in the Context of the Modern Papacy" (PhD diss., Heythrop College, 2013), http://www.heythrop.ac.uk/sites/default/files/docs/publications/theses/Rocco\%20PhD\%20Thesis.compressed.pdf.

${ }^{20}$ Ratzinger, Truth and Tolerance, 120. 
Ratzinger made the same distinction at the presentation of the Declaration Dominus Iesus, with the important addition that the Second Vatican Council represented the authentic idea of dialogue, whereas the new concept is rather an "ideology of dialogue," essentially equivalent to relativism and opposed to conversion and mission. ${ }^{21}$ It seems clear, then, that Ratzinger was never opposed to interreligious dialogue as such. Rather, he supported it as long as it did not succumb to relativism, lose sight of the truth and do away with the need for mission. ${ }^{22}$

\section{Before and After the Papal Election}

The first line of thought, which might be called the "truth/mission" model, thus appears consistent from the 1990s until the early years of the third millennium. However, around the beginning of Benedict's pontificate, a very different line of thought makes its first appearance. This view casts doubt on the possibility of an interreligious dialogue that aims at truth, and it can be traced to Ratzinger/Benedict's interaction with the Italian philosopher and politician, Marcello Pera, on the one hand, and Samir Khalil Samir, SJ, on the other.

The First Exchange with Marcello Pera

${ }^{21}$ Ratzinger, "Contesto e significato," 1.

${ }^{22} \mathrm{~A}$ certain tension remains between Ratzinger's emphasis on the truth of Christianity and the need for mission on the one hand, and his insistence that both sides are to be receivers and searchers for truth, on the other. The partners in dialogue are both learners, but not symmetrically. 
On May 12, 2004, the President of the Italian Senate, Marcello Pera, delivered a lecture at the Pontifical Lateran University. By coincidence, Cardinal Ratzinger delivered a lecture in the Capital Room of the Italian Senate the following day, and the two immediately noticed a great affinity in their respective "concerns about the spiritual, cultural, and political situation of the West." ${ }^{23}$ Subsequently, Ratzinger and Pera co-authored a book titled Without Roots, including the two lectures as well as an exchange of letters.

In his lecture, Marcello Pera raises the issue of interreligious dialogue, its purpose and its subject. Pera first defines dialogue as "an instrument through which to discover or approach the truth." 24 This seems in line with Ratzinger's thinking, but Pera then surprises the reader by stating that "in the context of Christian religion, dialogue cannot be an instrument for the discovery of truth, because Revelation plays that role." ${ }^{25}$ In contrast to Ratzinger's emphasis on the never-ending pilgrimage of truth, Pera says that truth in Christianity is "not a process but a state." 26

Having excluded the discovery of truth as a possible purpose of dialogue for the Christian, Pera says interreligious dialogue can be used to foster mutual understanding and to preach. As for the subject of dialogue, Pera again excludes the truth with a profoundly unRatzingerian comment: "for the believer there is no such thing as an interrogation or correction

${ }^{23}$ Joseph Ratzinger and Marcello Pera, Without Roots: The West, Relativism, Christianity, Islam, trans. Michael F. Moore(New York: Basic, 2007), xi.

${ }^{24}$ Marcello Pera, "Relativism, Christianity, and the West," in Ratzinger and Pera,Without Roots, $1-49$ at 28 .

25 Ibid.

26 Ibid. 
of mistakes." 27 After rebuking Vatican II's Nostra Aetate (NA) for its recognition of "elements of truth and grace" in other religions, Pera suggests replacing or at least assisting interreligious dialogue with a strong reaffirmation of the Christian faith and with an eradication of relativism. ${ }^{28}$ Toward the end of his essay, Pera claims he is not rejecting dialogue in toto but only a dialogue where it is presupposed that "one idea is as good as the other," i.e., the relativistic ideology of dialogue. ${ }^{29}$ However, he has in fact also rejected any interreligious dialogue that aims at truth, any theological dialogue between believers in revelation, as he will later explicitly admit.

Problems for interpretation and occasions for misunderstanding begin with Ratzinger's letter in response to Pera's lecture. On the one hand, the designation of truth as a "state" and its exclusion from the scope of interreligious dialogue is implicitly countered by the following typically Ratzingerian insight: "Believers must never stop seeking, while seekers are touched by the truth ... There are ways of partaking of the truth by which seekers and believers give to and learn from each other." ${ }^{30}$ On the other hand, Ratzinger's reply lacks any overt argument against

27 Ibid., 30.

28 Ibid., 29-33.

${ }^{29}$ Ibid., 45.

${ }^{30}$ Joseph Ratzinger, "Letter to Marcello Pera," in Ratzinger and Pera, Without Roots, 107-35 at 123. Although Ratzinger is here thinking specifically about secular seekers, the same idea generally applies to members of other religions. See Ratzinger, Truth and Tolerance, 21-22, 201-7. 
Pera's view of interreligious dialogue, and the Cardinal even declares: "I agree with you completely on everything."31

Did the exchange with Pera affect Ratzinger's thinking about interreligious dialogue? After the initial 2004 encounter, Ratzinger and Pera became friends and continued to exchange books and endorsements. ${ }^{32}$ Further interaction between the two will be analyzed later in this article; first we must examine Samir Khalil Samir's inside report on how the newly elected Pope Benedict XVI saw the issue of dialogue with other religions.

\section{The Report of Samir Khalil Samir}

In the first days of September, 2005, the first year of his pontificate, Benedict XVI held a closeddoor seminar with his famous Schülerkreis (Circle of Alumni) in Castel Gandolfo. The topic to be considered was the concept of God in Islam. Two Jesuits, Fr. Samir Khalil Samir, founder of Centre de documentation et de recherches arabes chrétiennes, and Fr. Christian Troll, were

\footnotetext{
${ }^{31}$ In context, the comment refers to the topic of relativism, which seems related to but not identical with the topic of interreligious dialogue. "I would now like to say a few words about relativism. As I said at the outset, I am most grateful for all that you explained so carefully in your lecture, and I agree with you completely on everything." Joseph Ratzinger, "Letter to Marcello Pera," 127-28.

${ }^{32}$ Pera provided an introduction for Ratzinger, Christianity and the Crisis of Cultures (San
} Francisco: Ignatius, 2005), and Pope Benedict XVI returned the favor in 2008 and 2009, with a letter and a foreword in endorsement of Pera's Why We Should Call Ourselves Christians: The Religious Roots of Free Societies (New York: Encounter, 2008). 
invited to share their expertise on the subject. In a 2006 article on the seminar, Samir made it known that the pope had discussed the theological topic of revelation and inspiration, emphasizing the differences between Islam and Christianity. According to the Islamic view, Muhammad was not inspired to write the Qur'an; rather, the Qur' an "descended" upon him. From this it is concluded that "the absolute nature of the Koran makes dialogue all the more difficult, because there is very little room for interpretation, if at all." ${ }^{33}$ Therefore, according to Samir, Pope Benedict is "proposing a way for Islam to work toward coexistence ... based not on religious dialogue, but on dialogue between cultures ... based on rationality and on a vision of man ... which comes before any ideology or religion.”34 The Jesuit further explains:

The essential idea is that dialogue with Islam and with other religions cannot be essentially a theological or religious dialogue, except in the broad terms of moral values; it must instead be a dialogue of cultures and civilizations. ... This step towards cultural dialogue is of extreme importance. In any kind of dialogue that takes place with the Muslim world, as soon as talk begins on religious topics, discussion turns to the Palestinians, Israel, Iraq, Afghanistan, in other words all the questions of political and

${ }^{33}$ Samir Khalil Samir, "When Civilizations Meet: How Joseph Ratzinger Sees Islam," Chiesa, April 5, 2006, http://chiesa.espresso.repubblica.it/articolo/53826bdc4.html?eng=y. For a more extended treatment of this argument, see Samir Khalil Samir, 111 Questions on Islam (San Francisco: Ignatius, 2008), 42-44. For a rebuttal, see Daniel Madigan, "Muslim-Christian Dialogue in Difficult Times", in Catholicism and Interreligious Dialogue, ed. James Heft (New York: Oxford University, 2011), 57-85, at 60-62.

${ }^{34}$ Samir, "When Civilizations Meet." 
cultural conflict. An exquisitely theological discussion is never possible with Islam: one cannot speak of the Trinity, of Incarnation, etc. ${ }^{35}$

Here, for the first time, we meet a completely different view about Pope Benedict's attitude toward interreligious dialogue. Instead of centering around truth and mission, this model focuses on moral values and cultural issues, excluding theology altogether. It might be called the "culture/values" model.

Before we proceed, three critical observations need to be made about Samir's report. First, there is an ambiguous equation of "theological" and "religious" dialogue. For example, Dialogue and Proclamation understands interreligious dialogue to include the dialogue of life, the dialogue of action, the dialogue of theological exchange, and the dialogue of religious experience ( $D P 42)$. The terminology used by Samir creates confusion, for it is not clear whether "religious dialogue" should be understood as a synonym with "interreligious dialogue" (a term Samir does not use) or with "theological dialogue." The latter seems to be intended, but it sounds more like the former, and indeed we will later have to deal with Pera claiming that Benedict XVI opts for intercultural dialogue instead of interreligious dialogue.

Second, the concrete arguments only concern Islam, but the essential principle is nevertheless applied to "other religions" as well. But other religions might not have a strong view of revelation, and their adherents might well enjoy discussing theological truth. The hasty and unfounded jump from Islam to all religions will also reappear with Pera in 2008.

Third, it is necessary to keep in mind that in this case we do not possess the ipsissima verba of Pope Benedict. What we have is Samir's interpretation, which is obviously colored by his own experiences of dialogue "with the Muslim world." Benedict seems to have spoken about

\footnotetext{
${ }^{35}$ Ibid.
} 
the difficulty ("all the more difficult") of theological dialogue with Islam, not its absolute impossibility ("never possible"). Furthermore, when Samir paraphrases the "essential idea" by saying that dialogue with other religions "cannot be essentially a theological or religious dialogue," we must ask whether the "cannot" should be understood as a matter of principle or a matter of strategy. Whereas Samir seems to imply the former, the evidence is insufficient to establish anything more than the latter, as far as Benedict is concerned.

In any case, the shift in attention described by Samir is significant in its own right. It was to leave a definite mark on the early years of Benedict XVI's papacy.

\section{Shifts in Strategy 2006-2008}

A famous example of the new strategy, also mentioned by Samir, was Pope Benedict's decision in March 2006 to place the Pontifical Council for Interreligious Dialogue (PCID) under the same president as the Pontifical Council for Culture (PCC), namely, Paul Poupard. ${ }^{36}$ In an interview, Cardinal Poupard interpreted the move as follows:

In fact, when one speaks of interreligious dialogue, one often thinks of a reflection of a doctrinal nature on common religious topics, such as the idea of God, sin, salvation, etc. However, this doctrinal dialogue calls for a common foundation, and this is not always the case with other religions. ... Thus dialogue is very difficult. Doctrinal dialogue is meaningful among Christians of various confessions with whom we share faith in Jesus

\footnotetext{
${ }^{36}$ Samir, "When Civilizations Meet." Contra Baum, "Interreligious Dialogue,” 10, Pope Benedict did not "close down" the PCID, whose staff remained intact, with the exception of the ex-president, Archbishop Michael Fitzgerald, who was appointed Apostolic Nuncio in Egypt.
} 
Christ. On the other hand, with believers of other religions dialogue is always possible on the basis of culture. ... Pope Benedict XVI therefore wishes to lead the dialogue with believers of other religions to the terrain of culture and of relations between cultures. ${ }^{37}$ Here, the term "interreligious dialogue" is used, and it is associated with "religious topics" or “doctrinal dialogue," which is reminiscent of Samir's use of the terms "religious" and "theological" dialogue. Poupard declares doctrinal dialogue with other religions "very difficult," but not impossible, thus confirming both the substance of Samir's report and his exaggeration.

The new strategy proved to be short-lived, however. In September 2006, Pope Benedict's Regensburg lecture caused a scandal, and when 38 Muslim scholars approached the Pope with a letter a month later, wishing to engage him in an open and honest interreligious (and theological!) dialogue, there was no response from the Holy See. In June 2007, the pope reversed the "personal union" of the PCID and the PCC, appointing Cardinal Jean-Louis Tauran as the new head of the PCID.

In October 2007, the famous follow-up letter from 138 Muslims, A Common Word Between Us and You, was published, again proposing an interreligious dialogue based on the double commandment of love of God and neighbor. Cardinal Tauran told the French newspaper La Croix that he appreciated the document to the extent that it promoted cooperation based on common values, but he repeated the pessimistic reflections originating from the Castel Gandolfo

37 “Christ and Religions, According to Cardinal Poupard," ZENIT Daily Dispatch, March 17, 2006, http://www.ewtn.com/library/CHISTORY/zchrstrelig.htm. 
meeting about the Muslim view of revelation and the ensuing impossibility of theological dialogue, adding the important qualification "for the moment." 38

Pope Benedict finally responded to the Muslims in November 2007. He had Cardinal Tarcisio Bertone, the Secretary of State, send a letter to Prince Ghazi bin Muhammad bin Talal, the author of the document, ${ }^{39}$ suggesting that a delegation of the 138 Muslims come to Rome. The correspondence ${ }^{40}$ led to the creation of the Catholic-Muslim forum, which met in the Vatican for the first time in November 4-6, 2008, and, in the words of Cardinal Tauran, "ended up doing theology unintentionally." 41

Before looking at the Catholic-Muslim forum more closely, however, we need to track the inner story of Pope Benedict's thinking and teaching on interreligious dialogue in these key years of 2007 and 2008. So far, all of the material questioning the established Ratzingerian truth/mission model has come from secondary sources (Pera, Samir, Poupard, Tauran). By

38 “Cardinal Tauran: 'La religion fait peur, car elle est pervertie par le terrorisme'," La Croix, October 18, 2007, http://www.la-croix.com/Religion/Actualite/Cardinal-Tauran-La-religion-faitpeur-car-elle-est-pervertie-par-le-terrorisme- NG -2007-10-18-527159.

${ }^{39}$ A Common Word Between Us and You: 5-Year Anniversary Edition (Amman: The Royal Aal Al-Bayt Institute for Islamic Thought), 252, http://rissc.jo/docs/20-acw/20-ACW-5.pdf.

${ }^{40}$ Letters available at "Christian Responses," A Common Word, http://www.acommonword.com/category/site/christian-responses/.

${ }^{41}$ Tom Heneghan, “Confusion over Pope's Letter Saying Interfaith Talks Impossible,"FaithWorld(blog), Reuters, November 24, 2008, http://blogs.reuters.com/faithworld/2008/11/25/confusion-over-popes-letter-saying-interfaithtalks-impossible/. 
looking at Benedict's own words, we will be able to evaluate the consistency and development of his thought in these years.

\section{Pope Benedict on Interreligious Dialogue 2007-2008}

We will consider four of the most relevant texts from Pope Benedict XVI on interreligious dialogue in 2007 and 2008. The first two texts, largely unnoticed, were originally oral answers given to questions posed by Catholic priests, whereas the third and fourth ones were prepared speeches given to interreligious audiences in Washington, DC and Vatican City.

Combining Proclamation and Dialogue

The first text is the only one of the four that predates A Common Word. Answering a question on the relationship between evangelization and interreligious dialogue in July 2007, Benedict XVI echoes Dialogue and Proclamation 82 in suggesting that the famous exhortation in 1 Peter 3:15 ("be ready to give an explanation to anyone who asks you for a reason for your hope," NABRE) provides the "necessary synthesis." According to the pope, the apostle Peter does not so much tell the Christians to proclaim the Gospel to everyone but to be always ready to give an answer for the hope that is within them. This is the ideal model to "combine proclamation and dialogue." $" 42$

${ }^{42}$ Benedict XVI, "Meeting of the Holy Father Benedict XVI with the Clergy of the Dioceses of Belluno-Feltre and Treviso" (Church of St. Justin Martyr, Auronzo di Cadore, July 24, 2007), 
Turning especially to the case of Muslims, the pope says that the first form of witness is "love of neighbor," whereas dialogue about the "great mysteries" is rather difficult. Still, it is not excluded, for there are commonalities "even in faith," such as a recognition of Jesus and love for the Virgin Mary, and these can serve as starting points for dialogue. The pope thinks that these difficult topics are more suitable for small and intimate meetings, whereas dialogue about common values, such as the contents of the Decalogue, can be realized more easily and in larger meetings:

The great substantial experience of the Ten Commandments is present and this seems to me a point that requires further investigation. Moving on to the great mysteries seems to me to be moving to a level that is far from easy and impossible to attain at large meetings. Perhaps the seed should enter hearts, so that here and there the response of faith in a more specific dialogue may mature. But what we can and must do is to seek a consensus on the fundamental values expressed in the Ten Commandments, summed up in love of neighbour and love of God, and which can thus be interpreted in the various life contexts. We are at least on a common journey towards the God of Abraham, Isaac and Jacob, the God who is ultimately the God with the human face, the God present in Jesus Christ. But if the latter step is to be made in intimate, personal encounters or small groups, the journey towards this God, from which derives [sic] these values that make life in common possible, I think this is feasible also at larger meetings. ${ }^{43}$

http://w2.vatican.va/content/benedict-xvi/en/speeches/2007/july/documents/hf ben$\underline{\text { xvi_spe_20070724_clero-cadore.html. }}$ 43 Ibid. 
The difficulty of making theological progress with Muslims, especially in large settings, explains the pope's strategic preference for a dialogue on values. At the same time, it is clear that Benedict XVI still believes what he wrote in 1997 about the interconnection between dialogue and mission. Even after the encounters with Marcello Pera and Samir Khalil Samir, he adheres to the possibility of interreligious and theological dialogue with Muslims, while recognizing its extreme difficulty.

Benedict XVI returned to the topic at a meeting with the clergy of Rome in February 2008. He again spoke of the two dimensions of dialogue and evangelization. According to the pope, it is first of all necessary to foster dialogue, cooperation, tolerance and respect of the other. But this does not "exclude the other dimension: the fact that the Gospel is a great gift, the gift of great love, of great truth, which we cannot only keep to ourselves alone." 44 We again find the ideas of dialogue, truth and evangelization together. What we also find is that the realistic or only goal is not the conversion of everyone but rather the presence of the Gospel in the world.

Reflecting on the examples of Mahatma Gandhi and St. Paul, the pope strikes a balance between those who would eliminate the idea of a universal mission and a call to conversion altogether, and those who think that the only salutary result in dealing with non-Christians would be their formal conversion:

The presence of faith in the world is a positive element, even if it does not convert anyone; it is a reference point. ... Let us think of the great figure of Mahatma Gandhi: although he remained firmly bound to his own religion, the Sermon on the Mount was a

\footnotetext{
${ }^{44}$ Benedict XVI, "Meeting with the Parish Priests and the Clergy of the Diocese of Rome"(Rome, February 7, 2008), https://w2.vatican.va/content/benedictxvi/en/speeches/2008/february/documents/hf_ben-xvi_spe_20080207_clergy-rome.html.
} 
fundamental reference point for him which shaped his whole life. Thus, the leaven of faith, even if it did not convert him to Christianity, entered his life. ... Let us think of St Paul. ... His desire was not so much to baptize all peoples as rather that the Gospel, hence, the fulfillment of history as such, be present in the world. ... In this sense, we indeed desire the conversion of all but allow the Lord to be the one who acts. What is important is that those who wish to convert have the possibility to do so and that the Lord's light appears over the world as a reference point for everyone. ... I do not know whether I have explained myself properly: not only do dialogue and mission not exclude each other, but they also help each other. ${ }^{45}$

Here it is again very clear that the pope has not abandoned his view on the interrelation of dialogue and mission in favor of a pure dialogue of cultures, coexistence and common values. Nor has he abandoned the idea that dialogue aims at truth. In fact, he is about to bring theological truth to the center of attention once more, this time more forcefully than ever before.

\section{Truth and Love}

The third text is the strongest and clearest statement in favor of the truth/mission model under Benedict's pontificate, and it comes from the apostolic journey to the United States in April 2008. Benedict XVI is addressing representatives of different religions, half a year after the publication of A Common Word. The speech deserves to be quoted at some length:

The broader purpose of dialogue is to discover the truth. What is the origin and destiny of mankind? What are good and evil? What awaits us at the end of our earthly existence?. .

\footnotetext{
45 Ibid.
} 
. We are living in an age when these questions are too often marginalized. Yet they can never be erased from the human heart. .. . Spiritual leaders have a special duty, and we might say competence, to place the deeper questions at the forefront of human consciousness, to reawaken mankind to the mystery of human existence, and to make space in a frenetic world for reflection and prayer. Confronted with these deeper questions concerning the origin and destiny of mankind, Christianity proposes Jesus of Nazareth. He, we believe, is the eternal Logos who became flesh in order to reconcile man to God and reveal the underlying reason of all things. It is he whom we bring to the forum of interreligious dialogue. ... Dear friends, in our attempt to discover points of commonality, perhaps we have shied away from the responsibility to discuss our differences with calmness and clarity. While always uniting our hearts and minds in the call for peace, we must also listen attentively to the voice of truth. In this way, our dialogue will not stop at identifying a common set of values, but go on to probe their ultimate foundation. ... As we have seen then, the higher goal of interreligious dialogue requires a clear exposition of our respective religious tenets. In this regard, colleges, universities and study centers are important forums for a candid exchange of religious ideas. $^{46}$

In this stunning text, Pope Benedict explicitly affirms what he has sometimes been presented as denying, namely, that interreligious dialogue aims at the truth about life's big questions, that it does not stop at peaceful coexistence and common values but proceeds to probe their ultimate

\footnotetext{
${ }^{46}$ Benedict XVI, "Meeting with the Representatives of Other Religions" (Pope John Paul II Cultural Center, Washington, DC,April 17, 2008), http://w2.vatican.va/content/benedictxvi/en/speeches/2008/april/documents/hf_ben-xvi_spe_20080417_other-religions.html.
} 
foundation, that it should be an open discussion about the various religious tenets, including the great Christian mysteries connected with Jesus of Nazareth. Perhaps inspired by A Common Word, the pope even envisages this kind of a dialogue being conducted in larger public settings such as universities can provide, and not only in small and intimate meetings.

Whereas the two texts treated earlier derive from in-house meetings with priests, this speech to non-Christians in Washington had a decidedly public character. It marked a noticeable shift in the Holy See's public strategy, as confirmed by a statement made by Cardinal Tauran in the same month of April 2008 in Nairobi, Kenya. Opening a five-day conference on interreligious dialogue, Tauran said that while theological dialogue had often been postponed to the future, Pope Benedict was now crossing the bridge: "that future is now." 47

The pope's speech in Washington is not an isolated exception but only the most striking example in a series of speeches of the same nature, such as those given later the same year to the Pontifical Council for Interreligious Dialogue and to the French Bishops. ${ }^{48}$ When it was time for the first Catholic-Muslim forum in early November 2008, not a few people were surprised at

\footnotetext{
47 “Cardinal Says Pope Giving New Direction to Dialogue,” ZENIT, April 23, 2008, https://zenit.org/articles/cardinal-says-pope-giving-new-direction-to-dialogue/.

${ }^{48}$ Benedict XVI, “Address of His Holiness Benedict XVI to Participants in the Tenth Plenary Assembly of the Pontifical Council for Interreligious Dialogue” (Rome, June 7, 2008), https://w2.vatican.va/content/benedict-xvi/en/speeches/2008/june/documents/hf_benxvi spe 20080607 interrelg-dialogue.html; Benedict XVI, "Meeting with French Episcopal Conference" (Sainte-Bernadette's Church, Lourdes, September 14, 2008), https://w2.vatican.va/content/benedict-Xvi/en/speeches/2008/september/documents/hf_benxvi_spe_20080914_lourdes-vescovi.html.
} 
both the possibility and the practical success of theological dialogue. ${ }^{49}$ In the speech of Pope Benedict to the participants of the forum on November 6, there is no opposition between the truth/mission model on the one hand and the culture/values model on the other. The pope begins by recognizing that the theme of the forum (Love of God, Love of Neighbour: The Dignity of the Human Person and Mutual Respect) highlights the "theological and spiritual foundations of a central teaching of our respective religions. ${ }^{50}$ Far from hiding central differences, Benedict XVI explains to the participants how for Christians the love of God and neighbor is rooted in the mysteries of God's Incarnation and Redemption:

The love of God became visible, manifested fully and definitively in Jesus Christ. He thus came down to meet man and, while remaining God, took on our nature. He gave himself in order to restore full dignity to each person and to bring us salvation. How could we ever explain the mystery of the incarnation and the redemption except by Love? This infinite and eternal love enables us to respond by giving all our love in return: love for God and love for neighbour. This truth, which we consider foundational, was what I wished to emphasize in my first Encyclical, Deus Caritas Est, since this is a central

${ }^{49}$ For example, Abdal Hakim Murad (alias Tim Winter), one of the Muslim representatives, remarked half-way through the forum:"I thought they didn't want to discuss theology but we've been doing that from the start." Heneghan, "Confusion."

${ }^{50}$ Benedict XVI, “Address of His Holiness Benedict XVI to the Participants in the Seminar Organized by the 'Catholic-Muslim Forum”" (Rome, November 6, 2008), https://w2.vatican.va/content/benedict-xvi/en/speeches/2008/november/documents/hf_benxvi_spe_20081106_cath-islamic-leaders.html. 
teaching of the Christian faith. Our calling and mission is to share freely with others the love which God lavishes upon us without any merit of our own. ${ }^{51}$

Having thus humbly but unashamedly proclaimed the Christian Gospel to the mixed audience, the pope goes on to recognize that "Muslims and Christians have different approaches in matters regarding God." Yet, Christians and Muslims can unite in "promoting genuine respect for the dignity of the human person and fundamental human rights, even though our anthropological visions and our theologies justify this in different ways." ${ }^{52}$ Even if fundamental theological differences remain, moral values can be shared:

There is a great and vast field in which we can act together in defending and promoting the moral values which are part of our common heritage. Only by starting with the recognition of the centrality of the person and the dignity of each human being, respecting and defending life which is the gift of God, and is thus sacred for Christians and for Muslims alike - only on the basis of this recognition, can we find a common ground for building a more fraternal world, a world in which confrontations and differences are peacefully settled, and the devastating power of ideologies is neutralized. My hope, once again, is that these fundamental human rights will be protected for all people everywhere. Political and religious leaders have the duty of ensuring the free exercise of these rights in full respect for each individual's freedom of conscience and freedom of religion. ${ }^{53}$

\footnotetext{
51 Ibid.

52 Ibid.

53 Ibid.
} 
In this speech, then, Pope Benedict is true to his long-standing vision, according to which interreligious dialogue is connected with truth and mission. He explains and proclaims the Christian faith, but he recognizes that progress in theological matters can be very difficult. If and when Muslims do not embrace the Christian Gospel, there can still be a "vast field" of cooperation in the area of "moral values." Accepting life as a gift of God can lead to finding the "common ground" desperately needed in order to settle the burning questions regarding "freedom of conscience and freedom of religion."

Thus far, we have seen that there is no principled opposition between what can be called the truth/mission model and the culture/values model in the mind of Pope Benedict XVI until November 2008. The radical understanding of the culture/values model, according to which interreligious or theological dialogue cannot be done at all, are only found in secondary sources, most importantly Marcello Pera and Fr. Samir Khalil Samir. The pope adopted a strategic preference for the culture/values model in the early years of his papacy but modified it after $A$ Common Word, returning to a strong emphasis on theological truth as the goal of interreligious dialogue.

\section{The Second Pera Exchange 2008-2009}

But the story continues with a most puzzling turn. On November 23, a mere 17 days after the happy conclusion of the Catholic-Muslim forum, Pope Benedict publicly endorsed Marcello Pera's book Why We Should Call Ourselves Christians: The Religious Roots of Free Societies, which contains a whole section on the impossibility of interreligious dialogue. Benedict XVI's 
letter, published in the Italian newspaper Corriere della Sera, is titled "Dialogue between Religions is Not Possible: Faith Cannot Be Put Into Parentheses.” The pope writes: Your analysis of the concepts of interreligious and intercultural dialogue is also particularly significant for me. You explain with great clarity that an interreligious dialogue, in the strict sense of the word, is not possible, while you urge intercultural dialogue which delves into the cultural consequences of the fundamental religious choice. While concerning this latter, a true dialogue is not possible without putting one's own faith into parentheses, it is necessary, in public exchange, to face the cultural consequences of the fundamental religious choices. Here dialogue, mutual correction and mutual enrichment are possible and necessary. ${ }^{54}$

The letter obviously raises many questions. Is the pope suddenly crossing the bridge again, this time in the opposite direction, and burning it behind him? For the first time, we seem to have the pope explicitly endorsing the impossibility of interreligious dialogue and juxtaposing it with intercultural dialogue. Before analyzing in detail the meaning and import of this letter, we will do well to take a short look at its rather confused reception.

Interpreting the Letter to Pera: Reception History

${ }^{54}$ Translation by the author based on the original and several earlier translations. Italian original: Benedict XVI, "Il dialogo tra le religioni non è possibile. La fede non si può mettere tra parentesi," November 23, 2008, Corriere della Sera, http://www.corriere.it/cultura/08_novembre_23/lettera_papa_benedetto_f01cee2c-b93f-11dd$\underline{\text { bb2c-00144f02aabc.shtml?refresh_ce-cp. }}$ 
In the immediate aftermath of the letter's publication, Vatican spokesman Federico Lombardi explained to the press that interreligious dialogue does not mean "questioning one's faith," rather, it "deals with the many other aspects that come from one's personal beliefs, cultural and historical, and their consequences." According to Lombardi's interpretation of Benedict's words, dialogue between the faiths is necessary, "even though it is impossible on strictly religious issues." Lombardi apparently interprets the phrase "strict sense of the word" with reference to the word "interreligious" rather than to the word "dialogue." 55

The widely followed American commentators, John L. Allen Jr. and George Weigel, saw the pope's words as reflecting his general strategy to focus on cultural dialogue, rights of minorities, coexistence, etc. Allen wrote that "this is not a judgment on whether religions should be talking to each other, but rather what they should be talking about." ${ }^{, 56}$ For Allen, the letter is "consistent with the approach to inter-faith relations Benedict has taken since his election to the papacy," but he makes no mention of the shift in the opposite direction evident in Washington earlier the same year. ${ }^{57}$ The same is true of George Weigel, who opined that Benedict is "trying to get the Catholic-Islamic dialogue out of the clouds of theory and down to brass tacks: how can

55 Richard Owen, “Pope Benedict Has Been 'Misinterpreted' on Interfaith Dialogue,’The Times Online, November 25, 2008, http://pluralism.org/news/pope-benedict-has-been-misinterpretedon-interfaith-dialogue/.

${ }^{56}$ John L. Allen Jr., "Benedict on Interreligious Dialogue: How Religions Talk with Each Other," NCRonline, November 28, 2008, http://ncronline.org/blogs/all-things-catholic/benedictinterreligious-dialogue-how-religions-talk-each-other.

57 Ibid. 
we know the truth about how we ought to live together justly, despite basic creedal differences?" But when had the Catholic-Islamic dialogue been up in the "clouds of theory"? 58

Finally, to cite a more recent example, Peter C. Phan writes that Ratzinger "has not always opposed interreligious dialogue" but that lately "Ratzinger prefers to speak of intercultural instead of interreligious dialogue," for "to his mind the latter requires a "bracketing' of one's religious beliefs and tends to lead to indifferentism, syncretism, relativism and secularism." ${ }^{59}$ The key phrases "intercultural dialogue instead of interreligious dialogue" and “"bracketing' of one's religious beliefs" are unmistakable echoes of the letter to Pera, but Phan's interpretation is not based on a close reading of the text, and it does not take into account all the evidence to the contrary.

To the embarrassment of professional theologians and church officials, perhaps the best attempt at an exegesis of the letter was made by the Reuters journalist Tom Heneghan, who noted the distinction between "dialogue" in the loose sense of "conversation" (supported by Benedict and evidenced by the Catholic-Muslim forum) and "dialogue in the strict sense of the word," meaning an exchange of ideas "with a view to reaching an amicable agreement or settlement." This strict definition of dialogue is inapplicable to interreligious dialogue, if "religions believe they possess the ultimate truth, so that no compromise is possible there." Heneghan concludes: "This is the context for his statement that dialogue is not possible "without putting one's faith in parentheses' - i.e. ignoring these fundamental differences." ${ }^{\circ 0}$

\footnotetext{
${ }^{58}$ Rachel Donadio, “Pope Questions Interfaith Dialogue,” New York Times, November 23, 2008, http://www.nytimes.com/2008/11/24/world/europe/24pope.html.

${ }^{59}$ Peter C. Phan, foreword to Dialogue Derailed, ix.

${ }^{60}$ Heneghan, "Confusion.”
} 
Although relying on a dictionary instead of the works of Benedict and Pera, Heneghan is on the right track in making the distinction between two meanings of "dialogue" on the basis of the qualification "in the strict sense." Heneghan is also right in calling attention to the qualifying words "without putting one's faith into parentheses," i.e. ignoring the religions' ultimate and mutually contradictory truth-claims. Based on Heneghan, then, we could paraphrase Benedict's controversial remark as follows: "Interreligious dialogue, in the sense of trying to achieve agreement on fundamental differences about ultimate truth, would only be possible by setting aside one's faith." But for a fuller and more accurate analysis, we need to take a look at the argument in Pera's book. This will allow us to appreciate the carefully considered wording of Benedict's response, which is not restricted to the Corriere della Sera letter but includes also the foreword Benedict wrote to the English edition of the book in 2009.

\section{Interpreting the Letter to Pera: The Argument of the Book}

The context for Pera's discussion of interreligious and intercultural dialogue is the question of whether Islam can find a way to coexist with Christianity and Judaism. ${ }^{61}$ Somewhat shockingly, Pera begins by condemning the entire approach taken by the Catholic Church in and since Nostra Aetate, namely, interreligious dialogue. He tries to interpret the Regensburg lecture of Benedict XVI as an alternative proposal, that is, intercultural dialogue instead of interreligious dialogue. ${ }^{62}$

\footnotetext{
${ }^{61}$ Pera, Why We Should, 133.

${ }^{62}$ Ibid., 133, 136. The Regensburg lecture speaks of a "dialogue of cultures and religions" and supports no dichotomy between interreligious and intercultural dialogue. On the contrary, the
} 
This is in open opposition to Benedict's many explicit endorsements of both NA and interreligious dialogue, and it must have made the pontiff feel uncomfortable. In fact, in the preface written for the American edition in 2009, Benedict XVI evidently sympathizes with the confused reader and seeks to offer a charitable interpretation. Benedict writes: "The reader may be surprised at first that Pera holds that interreligious dialogue, in the strict sense of the word, is not possible, while at the same time he greatly stresses the need for intercultural dialogue. How should we understand this?"63

Before further analyzing Benedict's reception of Pera, let us go through the argument as presented in Pera's book. The key phrase about the "strict sense," echoed in the pope's letter, is explained by Pera as follows: in the "strictest and most technical sense," dialogue presupposes "that the interlocutors be open to revision and to the rejection of the truth with which they began their dialectical exchange." The principle of dialogue is: "I may be wrong and you may be right, but by an effort we may get nearer to the truth." ${ }^{64}$

This, then, is the "strict sense" of the word "dialogue." It is not relativism, for there clearly is a truth to be achieved, but it presupposes a certain agnosticism, skepticism, or at least fallibilism about one's own faith, a willingness to put it in question, up for discussion. For Pera, this sort of dialogue is impossible between monotheistic and revealed religions, which all have their own non-negotiable truth:

paragraphs that deal with Islam are concerned not only with "cultural" issues such as religious liberty, but also with the theological question of the rationality of God.

${ }^{63}$ Benedict XVI, foreword to Why We Should Call Ourselves Christians, by Marcello Pera (New York: Encounter, 2008), viii.

${ }^{64}$ Pera, Why We Should, 133. 
How can there be an authentic religious dialogue if monotheistic and revealed religions are holistic systems, each with its own truth and its own criteria for ascertaining truth? If the believer of one religion cannot admit the truth of another? He who says I am the truth excludes anyone else from making the same claim.... Dialogue has no meaning if at the outset both say: 'This is the truth and I will never change my mind.' In such a case, at most, their encounter may be an exchange of information, useful for learning about each other but unable to produce agreements on substantial issues. ${ }^{65}$

The main problem with Pera's rather bizarre argument is that Nostra Aetate and subsequent Catholic teaching, including Dialogue and Proclamation and Ratzinger, have not used the term "(interreligious) dialogue" in such a strict sense, and such a definition would by no means be required for solving the original question about peaceful coexistence. Nostra Aetate is content with promoting mutual understanding and respect as well as recognizing values found among non-Christians (NA 2, 4), but Pera understands "interreligious dialogue" very narrowly, assuming that it should by definition succeed in uniting the religions under one agreed truth, the very thing Ratzinger denied in $1997 .{ }^{66}$ Since this kind of union cannot happen, Pera concludes that there is "no common ground" and that interreligious dialogue is "simply impossible."67

Pera's proposed alternative is "intercultural dialogue" about the religions' "cultural (especially ethical) consequences," such as what rights are granted or denied, what kind of

\footnotetext{
65 Ibid.
}

${ }^{66}$ For Pera, in a true interreligious dialogue, "essential religious consequences" would have to follow, namely, "Christianity and Islam would have to be the same religion expressed in different words." Ibid., 135.

${ }^{67}$ Ibid., 136. 
relationships or institutions are allowed or banned, etc. The object of intercultural dialogue is "not, say, the Trinity or transubstantiation, but rather equality, freedom, tolerance, and the like." ${ }^{\prime 68}$ On these issues, an authentic debate can take place, and one religion can be judged better than the other. This judgment does not disprove the religion's "dogmatic core," but, significantly, can lead to its reinterpretation or abandonment. Even if conversion does not occur, a "genuine discussion has taken place." 69

Pera's application of different standards to interreligious and intercultural dialogue is highly questionable. In reality, many Christians and Muslims might be far more dogmatic about their cultural convictions than about their theological ones. Disappointingly, Pera's treatment does not answer the original question of whether Islam can find a way to coexist with Christianity and Judaism; ultimately it aims at a quick cultural comparison where Western values are the standard and Islam—quite predictably— "loses." ${ }^{70}$ Europe is then warned that the "integration of Muslims means surrendering to them."71

${ }^{68}$ Ibid., 139.

${ }^{69}$ Ibid., 137-38. Pera is likely unaware of an entire culture of Christian-Muslim debates, especially lively in the English-speaking world, where authentic discussions take place on matters of dogma and interpretation as well, even if agreement is not reached (see, e.g., the many debates of Shabir Ally and James White with each other and other opponents). Pera also ignores the possibility that dogmatist-exclusivist believers might change their minds in and through theological dialogue.

${ }^{70}$ Ibid., 139.

${ }^{71}$ Ibid., 140. 
This might make the reader wonder why Pope Benedict publicly endorsed Pera's book in the first place. It must be kept in mind that the two had become friends and that the book dealt with other issues of interest to Benedict as well. At the same time, it must be recognized that Pera's argument against interreligious dialogue did make Benedict XVI think about the subject in greater depth.

Interpreting the Letter to Pera: A Multiply Qualified Endorsement

The title of the letter published in Corriere della Sera almost certainly originates with the editors of the newspaper, rather than Benedict XVI himself. In the letter, Benedict XVI does not declare interreligious dialogue impossible, but he does praise Pera's exposition of the impossibility of interreligious dialogue "in the strict sense of the word." Instead of taking the words "you explain with great clarity" as purely descriptive (thus exempting Benedict from agreeing), the reader familiar with Benedict's commitment to interreligious dialogue should stress the key qualification "in the strict sense," which on the basis of Pera's book refers to an interreligious agreement about fundamental theological differences.

It must be further noted that Benedict does not wish to bring the sentence to an end without introducing his own key term decisione religiosa di fondo, variously translated as "religious option which lies beneath", "root religious option", "essential faith decision" or "fundamental religious choice." 72 Whereas Pera's book distinguishes between a religion's "dogmatic core," its interpretive principles, and its cultural consequences, Benedict prefers to

${ }^{72}$ Since the Italian term is to reappear in 2012 as scelta di fondo, the translation "fundamental religious choice" is adopted in this article. 
talk about a "fundamental religious choice" and its consequences. He goes on to specify that a true dialogue about this fundamental choice is not possible "without putting one's faith into parentheses," adding two more qualifications to the alleged impossibility of interreligious dialogue.

But what is a "fundamental religious choice"? The term echoes parts of Truth and Tolerance, where it seems to mean a non-demonstrable (but still rationally defensible) faith decision between a few basic options such as Christianity, Islam, atheism and Asian mysticism. ${ }^{73}$ In sum, what Benedict accepts from Pera's argument is that dialogue, in the sense of assuming the possibility of error and the need for correction, is impossible when it comes to the fundamental choice between Christianity, Islam and other basic options-without putting one's faith into parentheses. It really comes down to a tautology: one cannot question one's faith without questioning one's faith.

Likewise, in his foreword to the English-language version of Pera's book, Benedict reads Pera as saying that "for true believers, the essential faith decisions are not open to discussion." 74 But this is very different from any general impossibility of interreligious or theological dialogue. Even the Trinity can be talked about: it can be explained and defended, but the ultimate "yes or no" to it is a matter of faith, not of negotiation.

The question, for example, of whether God is or is not triune is not in the final analysis a subject for discussion; on this issue, the yes or no that one gives to the question is a decision taken in faith. Certainly, one can try to explain the inner logic of this apparently

\footnotetext{
${ }^{73}$ See Ratzinger, Truth and Tolerance, 32, 83-85, 181.

${ }^{74}$ Benedict XVI, forewordto Why We Should, viii.
} 
contradictory vision and clarify misunderstandings and erroneous interpretations; however, the yes or no as such is not a subject for discussion. ${ }^{75}$

Despite the enlightening clarification, it might still be asked why the fundamental religious choices could not be discussed as such and why questioning one's faith appears as such an unwanted feature. Isn't it a prerequisite if dialogue is supposed to include the possibility of conversion? Here Benedict's letter adds one more subtle qualification to Pera's unsophisticated rejection of interreligious dialogue, namely the words "in public exchange." Pera never made it clear whether he was talking about individual believers engaging in private dialogue, or formal settings where official representatives attempt to reach agreements. The logic of the argument makes better sense within the latter scenario, and Benedict could be interpreted as narrowing it down to that. In other words, dialogue in larger, more official, public settings should concern the cultural consequences of faith, whereas in private settings, initial convictions could feasibly be "put into parentheses" and the "yes or no" to fundamental religious choices could be discussed. However, it must be admitted that this proposal would need to deal with certain discrepancies from both earlier and later papal speeches. ${ }^{76}$

In any case, Benedict sends an important message by concluding that under the conditions specified, "dialogue, mutual correction and mutual enrichment are possible and

\footnotetext{
${ }^{75}$ Ibid., viii-ix.

${ }^{76}$ The reader is referred to the 2008 Washington speech where the Pope seemingly encourages public probing of fundamental choices, as well as the address from 2012 treated later where the Pope seems to exclude discussing fundamental choices altogether. One might try to avoid the difficulty by appealing to the different circumstances or unsystematic nature of these speeches.
} 
necessary." This is a gentle but firm rejoinder to Pera: we can and must also be willing to be corrected and enriched by other religions, including Islam.

In conclusion, it seems clear that Benedict XVI has followed his own advice from 1997 and looked behind the alien appearances of Pera's argument to see if he can find some hidden truth there. He has thought deeply about Pera's reasoning and reinterpreted it charitably as a loyal friend. Unfortunately, the subtle letter easily lends itself to misunderstandings, and it could rightly be asked whether it was fitting for the pope to publicly honor Pera's book in such a way. In any case, Benedict's thinking about interreligious dialogue seems to have benefited from the exchange, as is seen from his last major papal contribution to the subject.

\section{Christmas Greetings to the Roman Curia 2012}

Benedict's Christmas greetings to the Roman Curia in December 2012, a mere two months before the historic end of the pontificate, include a lengthy treatment of interreligious dialogue that contains clear echoes of the Pera exchange, such as excluding theological topics and "fundamental religious choices" from the scope of interreligious dialogue. Benedict XVI begins by mentioning the various levels of dialogue, as in London two years earlier, ${ }^{77}$ but he only really

${ }^{77}$ In London, the pope spoke about the different levels of dialogue (life, action, theology, religious experience), following $D M 28-35$ and $D P$ 42. He also made explicit the important distinction between private and formal conversations. See Benedict XVI, "Meeting with Clerical and Lay Representatives of Other Religions" (St Mary’s University College, London,September 17, 2010), http://w2.vatican.va/content/benedict-

xvi/en/speeches/2010/september/documents/hf_ben-xvi_spe_20100917_altre-religioni.html. 
gets to the "dialogue of life," which then opens up the discussion to interreligious dialogue as a whole.

This [dialogue of life] will not involve discussing the great themes of faith - whether God is Trinitarian or how the inspiration of the sacred Scriptures is to be understood, and so on. It is about the concrete problems of coexistence and shared responsibility for society, for the state, for humanity. In the process, it is necessary to learn to accept the other in his otherness and the otherness of his thinking. To this end, the shared responsibility for justice and peace must become the guiding principle of the conversation. ${ }^{78}$

Benedict prioritizes shared social responsibility and the need to "accept the other in his otherness." He still advocates both a dialogue of truth and a dialogue of values, but the inviolability of "fundamental religious choices," drawn from the exchange with Pera, seems to have shaped his vision of interreligious dialogue, weakening the old emphasis on the missionary aspect:

A dialogue about peace and justice is bound to move beyond the purely pragmatic to become an ethical struggle for the truth and for the human being: a dialogue concerning the values that come before everything. ...Even if the fundamental choices themselves are not under discussion, the search for an answer to a specific question becomes a process in which, through listening to the other, both sides can obtain purification and enrichment. Thus this search can also mean taking common steps towards the one truth,

\footnotetext{
${ }^{78}$ Benedict XVI, “Address of His Holiness Benedict XVI on the Occasion of Christmas Greetings to the Roman Curia” (Rome, December 21, 2012), http://w2.vatican.va/content/benedict-xvi/en/speeches/2012/december/documents/hf_benxvi_spe_20121221_auguri-curia.html.
} 
even if the fundamental choices remain unaltered. If both sides set out from a hermeneutic of justice and peace, the fundamental difference will not disappear, but a deeper closeness will emerge nevertheless. ${ }^{79}$

Three times in three sentences Benedict makes reference to the inviolability of the "fundamental choices" (scelte di fondo) or "fundamental difference." In dialogue, they are not under discussion, they are not altered, they do not disappear. Yet, equally significant is the threefold insistence that this does not render interreligious dialogue meaningless: both sides can obtain purification and enrichment, common steps toward the one truth can be taken, and a deeper closeness between the two dialogue partners can emerge. Again, there is again a certain yes to Pera, but there is also an unmistakable no to Pera.

At this point the question of the relationship between dialogue and conversion must return. If the fundamental choices are assumed to remain unaltered in interreligious dialogue in general, is there any more room for mission in the context of dialogue? In a most interesting passage, Pope Benedict makes a clear distinction between dialogue and mission, showing greater understanding than before toward those who insist on keeping the two separate:

Two rules are generally regarded nowadays as fundamental for interreligious dialogue: 1 . Dialogue does not aim at conversion, but at understanding. In this respect it differs from evangelization, from mission; 2. Accordingly, both parties to the dialogue remain consciously within their identity, which the dialogue does not place in question either for themselves or for the other. These rules are correct, but in the way they are formulated here I still find them too superficial. True, dialogue does not aim at conversion, but at better mutual understanding - that is correct. But all the same, the search for knowledge

\footnotetext{
79 Ibid.
} 
and understanding always has to involve drawing closer to the truth. Both sides in this piece-by-piece approach to truth are therefore on the path that leads forward and towards greater commonality, brought about by the oneness of the truth. ${ }^{80}$

Benedict here repeatedly affirms that dialogue does not aim at conversion but at better understanding: this generally accepted rule is said to be "correct," although it must be related to the fact that dialogue aims at truth. The stress on the concept of truth is familiar, but there is no longer such a close connection between dialogue and mission as there was at the turn of the millennium. In the context of dialogue, the Benedict of 2012 seems to be content with "greater commonality," saving his treatment of proclamation for a separate section. The concept of truth now serves as a critical reminder to those who oppose interreligious dialogue based on a voluntaristic religious identity (e.g. "We are Europeans, and Europe is Christian!") and fear that entering into dialogue would somehow put that identity at risk:

As far as preserving identity is concerned, it would be too little for the Christian, so to speak, to assert his identity in a such a way that he effectively blocks the path to truth. Then his Christianity would appear as something arbitrary, merely propositional. He would seem not to reckon with the possibility that religion has to do with truth. On the contrary, I would say that the Christian can afford to be supremely confident, yes, fundamentally certain that he can venture freely into the open sea of the truth, without having to fear for his Christian identity. To be sure, we do not possess the truth, the truth possesses us: Christ, who is the truth, has taken us by the hand, and we know that his hand is holding us securely on the path of our quest for knowledge. Being inwardly held by the hand of Christ makes us free and keeps us safe: free - because if we are held by

\footnotetext{
${ }^{80}$ Ibid.
} 
him, we can enter openly and fearlessly into any dialogue; safe - because he does not let go of us, unless we cut ourselves off from him. At one with him, we stand in the light of truth. $^{81}$

A far cry from Pera's "I am the truth" and "simply impossible," Pope Benedict again repeats the teaching of Dialogue and Proclamation, ${ }^{82}$ adding that the Christian can be "supremely confident" in his "quest for knowledge" and enter "openly and fearlessly into any dialogue." Indeed, Benedict's 2012 speech might help to revise widely spread ideas about him being fearful and suspicious of interreligious dialogue, largely based on misinterpretations of the letter to Pera and a false equation of Dominus Iesus with Ratzinger's personal attitude. A case could be made that if there is an official document that guides Benedict's teaching on interreligious dialogue, it is much more the 1991 PCID document Dialogue and Proclamation than it is the CDF declaration Dominus Iesus. ${ }^{83}$

${ }^{81}$ Ibid.

${ }^{82}$ See DP 49: "In the last analysis truth is not a thing we possess, but a person by whom we must allow ourselves to be possessed. This is an unending process. While keeping their identity intact, Christians must be prepared to learn and to receive from and through others the positive values of their traditions. Through dialogue they may be moved to give up ingrained prejudices, to revise preconceived ideas, and even sometimes to allow the understanding of their faith to be purified."

${ }^{83}$ A separate study would be needed to further substantiate this claim in relation to the publication of $D I$ and the investigation of Jacques Dupuis. Here, at least three factors would have to be taken into account: first, the role played by Ratzinger's secretaries in drafting the official CDF documents; second, Ratzinger's personal respect for Dupuis and his work; third, the fact 


\section{Summary and Conclusion}

Pope Benedict XVI's attitude toward interreligious dialogue poses no small challenge for the interpreter. In some texts, both as Cardinal Ratzinger and as Pope Benedict, we find a strong emphasis on truth and a close connection between dialogue and mission. In other texts, we find a clear movement away from theology and a prioritization of peaceful coexistence, common values, mutual understanding, even an apparent rejection of the concept of interreligious dialogue. Both of the two paradigms, the truth/mission model and the culture/values model, have been detected and discussed by theologians and commentators, but rarely if ever in relation to each other. No simplistic conversion from one paradigm to the other can be maintained; instead, we have a sort of a zigzag movement whose most significant turns can be placed at 2004-2006, 2007-2008 and 2008-2009.

At the turn of the millennium, Cardinal Ratzinger emphasized the interconnection between dialogue and mission, but he never reduced dialogue to mission. Around the beginning of Benedict's papacy, two sources close to the pope emerge that question this truth/mission model. Both Marcello Pera and Samir Khalil Samir argue that theological dialogue with Islam (and perhaps also other religions) is impossible and that Pope Benedict, seeing this, wishes to

that Ratzinger is known to have regretted some of the formulations in Dominus Iesus. See William R. Burrows, ed., Jacques Dupuis Faces Inquisition: Two Essays by Jacques Dupuis on Dominus Iesus and the Roman Investigation of His Work (Eugene: Wipf and Stock, 2012), xxi, 10; Ratzinger, Truth and Tolerance, 52-53; Peter Seewald, Benedict XVI: An Intimate Portrait (San Francisco: Ignatius, 2008), 215-216. 
engage in a different kind of dialogue instead, a dialogue of cultures and values. Benedict never adopts the exaggerated position of Samir and Pera, but his actions and teachings confirm a change in strategy and emphasis. In 2007-2008, probably encouraged by the publication of $A$ Common Word, Benedict returns to a strong emphasis on theological truth, most notably in his speech in Washington in April 2008. But in November of the same year, the tide turns again. Benedict XVI's subtle endorsement of Marcello Pera's book Why We Should Call Ourselves Christians caused much misunderstanding and confusion, but it also marked the introduction of a significant new element into the pope's thinking about interreligious dialogue. Both in his foreword to the English-language edition of the book and in his 2012 Christmas greetings to the Roman Curia, Pope Benedict states that in dialogue, "fundamental religious choices" are not under discussion as such. This logically leads to a separation of dialogue and mission (in the narrow sense of aiming at the other's conversion), but it is not entirely clear whether this should apply to all forms of dialogue or only formal and "public exchange." In the 2012 speech, the last lengthy treatment of the topic while in office, the pope begins to speak about the "various dimensions" of interreligious dialogue, but in fact only mentions the "dialogue of life" and then covers the entire topic. Lacking a more systematic treatment, we are left with some unresolved questions and tensions, but Benedict's overall commitment to interreligious dialogue as expressed in Nostre Aetate, Dialogue and Mission, and Dialogue and Proclamation seems well established.

In sum, if Benedict XVI's attitude to interreligious dialogue had to be put in a sound-bite, it would not be John Allen's "interreligious dialogue no, intercultural dialogue yes." ${ }^{\prime 4}$ A much more fitting alternative could be found in the well-known Arabic words Allahu akbar-God is

\footnotetext{
${ }^{84}$ Allen, "Benedict on Dialogue."
} 
greater. These words entail the existence of God, and hence, an acceptance of ultimate truth and a rejection of relativism. But they also include the message that this truth is always greater than us, that we never fully possess it, which in turn requires an attitude of humility and a willingness to learn from one another. Contra Marcello Pera, interreligious dialogue is not mission impossible. In his farewell speech to the clergy of Rome in 2013, Pope Benedict once more spoke about the urgency of interreligious dialogue and reminded his audience of the importance of Vatican II's Nostra Aetate. As his final word on the matter, the pontiff concluded that it is both "necessary and possible to enter into dialogue, and thus to become open to one another and to open everyone to the peace of God." 85

${ }^{85}$ Benedict XVI, "Meeting with the Parish Priests and the Clergy of Rome" (Rome, February 14, 2013), http://w2.vatican.va/content/benedict-xvi/en/speeches/2013/february/documents/hf_benxvi_spe_20130214_clero-roma.html. 